\title{
Children's experiences of migration: moving in the wake of AIDS in southern Africa
}

\section{Lorraine van Blerk $\uparrow$, Nicola Ansell}

Department of Geography and Earth Sciences, Brunel University, Kingston Lane, Uxbridge UB83PH, England; e-mail: lorraine.van.blerk@brunel.ac.uk, nicola.ansell@brunel.ac.uk Received 19 April 2004; in revised form 12 October 2004

\begin{abstract}
Despite the recent significance children's geographies have been afforded within many geographical subdisciplines, their experiences of migration have received relatively little attention. However, children do migrate and their migration is often distinct from that of entire households. In this paper we explore children's migration in southern Africa within the context of the HIV/AIDS pandemic, focusing in particular on the impacts of moving house on children's sociospatial experiences. Migration has consequences for several areas of children's lives, and the nature of those consequences is shaped by the context within which migration takes place. In southern Africa AIDS is an unavoidable aspect of the sociospatial context, but the impact it has on children varies. This exemplar has wider implications for two areas of geographical research. First, in the paper we advocate the importance of including children's experiences of migration within culturally informed studies of migration. Second, there is a need for research in children's geographies to extend beyond the microlevel. We advocate a refocusing of research beyond children's static relationship to environments to also encompass children's transient geographies in discussions of their life experiences.
\end{abstract}

\section{Introduction}

Geographical research with children has intensified over recent years with growing acceptance that children are social actors creating their own unique geographies (Aitken, 2001; Holloway and Valentine, 2000a; 2000b; Katz, 1993; Matthews et al, 1999). Children-focused research has been brought to the forefront of many geographical subdisciplines, in line with the recognition that society is culturally diverse and composed of complex individuals with different ways of seeing and understanding the world. With a few notable exceptions the burgeoning literature on children's geographies has focused on children's microgeographies and on their specific relationships to environments such as the home, school, playground, and street (Beazley, 2000; Matthews et al, 2000; Punch, 2000; Smith and Barker, 2000; Valentine, 1996). There have been fewer acknowledgements that children are involved in wider geographies, moving across greater distances and adapting to changing surroundings and environments.

Even in largely sedentary Western societies, a proportion of children engage in migration both within and outside the family context. This may include moving home, movements to and from boarding schools, movements into and out of care facilities, or movements between the homes of separated parents. Across much of Africa, however, societies are more fluid, with migration contributing to normal household survival (McDowell and de Haan, 1997). Given children's involvement in livelihood strategies it is unsurprising that many African children experience migration.

In this paper we discuss children's experiences of migration within the context of the HIV/AIDS pandemic in southern Africa. Using empirical material from Malawi and Lesotho we argue that migration research needs to recognise children as social actors and to consider the unique forms of migration they participate in, both 
accompanied and unaccompanied, and their consequences for children's lives. Migration has implications for several areas of children's lives, and the nature of those implications is shaped by the context within which migration takes place. In southern Africa AIDS is an unavoidable aspect of the sociospatial context, but the impact it has on children and their migration experiences varies. In focusing on movement between places, and adaptation to new environments, we further advocate a refocusing of the scale at which children's geographies are considered.

\section{Bringing children's geographies into migration research}

In recent years population geographers have called for greater awareness of the rootedness of migration within everyday life experiences rather than simply examining single movements across space (McHugh, 2000). This has led them to engage with the cultural circumstances surrounding migration rather than simply focusing on statistical assessments of demographic change (Findlay and Li, 1997; Halfacree, 1995; Halfacree and Boyle, 1993; Ogden, 1998; Skeldon, 1995). Findlay and Li (1999) state that rather than focusing attention only on spatial models and migration patterns researchers also need to examine why migration occurs, particularly in relation to changing cultural contexts of migrants' everyday lives. This new culturally informed migration literature increasingly emphasises the value of ethnographic methods (see, for example, Findlay and Li, 1997; Gutting, 1996; Lawson, 2000; Potts, 1995).

Despite this alternative approach to migration studies, research remains largely adult focused, with children's migration excluded or unsatisfactorily subsumed within family migration (McKendrick, 1999). However, children do migrate and their migration has implications outside the family. Within a Western context several historical studies have explored the nature and consequences of children's migration. Davin (1996), for instance, found that children of diverse cultural backgrounds were attending London schools in the late 19th century. Here, children's migration experiences affected their schooling and community interactions including friendships. Although these London children had moved with their parents, Coldrey (1999) demonstrates that children had been moving separately from adult kin since the 17 th century through the forced migration of 'young vagrants' from Britain's city streets to family farms in the New World. Similarly, McClure (1981) points to children's individual migration in her discussion of the development of London's foundling hospital in the 18th century. Here, infants were first placed with wet nurses in country locations, then at the age of 3 years they were returned to London for institutional care, and again around the age of 11 or 12 years they were moved to new locations as domestic workers, stable hands, and apprentices, each stage entailing some disruption and distress for the children.

Contemporary children's migration in the West has received less attention. Dobson and Stillwell (2000) have recently examined the educational reasons for, and consequences of, 'moving house' in the United Kingdom. Their call for a 'research agenda' for children's migration, while drawing much needed attention to the lack of childrenfocused migration research within geography, centres on only one aspect of this: British children's migration in relation to education.

Outside the Western context, particularly in Africa and South Asia, children commonly migrate as part of independent or household livelihood strategies. Some move in order to look for work, going onto the streets, or because they are displaced (Bourdillon, 1999; Camacho, 1999; Kimane and Mturi, 2001; Young, 2004); others move to help relatives or because of marital dissolution in their families (Urassa et al, 1997). Employment-related migration has received particular attention as an important aspect of children's independent migration strategies. Research in the Philippines has, for instance, highlighted the role of young domestic workers in family survival. 
Here children, usually girls, move to Metro Manila in search of employment as a means for supporting their families (Camacho, 1999; Lauby and Stark, 1988).

Some studies address the impacts of migration on children but they tend to concentrate on parental separation through adult migration rather than on children as migrants. Research in the Ecuadorian Andes demonstrates the link between parental migration, usually of the father, and the onset of a depression-like disorder (nervios) in children (Pribilsky, 2001). Kandel and Kao's (2001) work on Mexico also discusses the impacts of family separation through migration on children in the household, particularly in relation to their educational aspirations.

A small number of international migration studies, undertaken from a sociological perspective, also illustrate children's role as active migrants. For example, Orellana et al's cross-cultural work focuses on children as migrants, looking at how they participate in family migration and sometimes take the lead (2001). Although the decision to move is generally made by adults, children's participation in migration is often important for overall family survival. They discuss how African-American children engage in circular migration to help relatives and how children can act as "social, emotional and economic 'linchpins' for households that span transnational borders" (page 588; see also Candappa and Egharevba, 2002).

These studies, although sparse, draw attention to the extent and complexity of children's migration and touch on the important implications this has for the social and economic lives of young migrants. However, they rarely consider the implications of the spatiality of such movements. A research agenda for children's migration among geographers must reflect the diversity of the movements children engage in, both accompanied and unaccompanied, as well as their implications for shaping children's sociospatial experiences.

Consideration of children's migration experiences within the ambit of geographical research calls for a refocusing of the scale at which children's geographies are examined. Much research in children's geographies has concentrated on children's experiences of their immediate environments. Rather than simply giving attention to the local situations in which children live (although this is also important), it is necessary to recognise that local spaces are porous, influenced both by global processes (Holloway and Valentine, 2000b; Katz, 1993; 1994; Massey, 1998) and by the interconnectedness of (family) relations across space. Children's lives are not lived simply at the microscale. Their lives are not static, and often involve movement across and between spaces. The experience of movement and adaptation to new environments are key geographical elements of many young people's lives. Children's migration geographies may be influenced both by distance and by the circumstances surrounding the decision to move, the latter of which are often individual or family reactions to the impacts of much larger societal processes (Young, 2004). The resulting change in local experience influences young migrants as they adapt to new circumstances through interaction with new people and places. We demonstrate that such movements can be of critical importance in young people's lives.

\section{Children, AIDS, and migration in southern Africa}

The existing migration literature attributes children's migration largely to economic or educational aspirations. These reasons are applicable to children in southern Africa, where the history of labour migration is such that families are often spatially dispersed, and it is not uncommon for children to be sent to live with relatives resident elsewhere on a temporary or permanent basis. Although children's unaccompanied migration is not a new phenomenon, in the context of the AIDS pandemic children's displacement is becoming more common (Fontes et al, 1998). The infection and subsequent death of 
much of the productive population in southern Africa are leading to the breakdown and dispersal of extended families (WHO and UNICEF, 1994), yet AIDS-related migration, and in particular its sociospatial impacts, remains largely neglected in migration research.

Southern Africa is currently the region worst affected by AIDS, with adult infection rates ranging from $3.9 \%$ in Angola to $38.8 \%$ in Swaziland; the majority of countries in the region have rates over 20\% (UNAIDS, 2004). Those infected are mostly in the economically productive age range, resulting in many children losing their parents and other relatives (Grainger et al, 2001). The societal implications of AIDS are diverse and it is important to recognise that AIDS impacts on children not only by depriving them of their adult relatives but in numerous other ways. Indeed, it is important not to focus on 'AIDS-affected children' as a distinct social category (let alone to focus on 'AIDS orphans'). The scale of the pandemic is such that few children are entirely unaffected by AIDS, and, although the impacts of AIDS are discernable, they are far from singular or monolithic. Some children have to face the death of one or both parents (with whom they may or may not reside) or that of other close relatives; some are involved in caring for sick relatives; some find they have to share resources with cousins who are orphaned. The problems that confront children affected by AIDS are not in essence different from those confronting other children whose relatives become sick or die and who grow up amid poverty.

The indirect effects of AIDS on children are well documented in social science literature and policy documents. Hunter and Williamson (2000a) list several impacts including loss of family and identity; psychosocial distress; increased malnutrition; loss of health care; increased demands for labour; fewer opportunities for schooling; loss of inheritance; forced migration and homelessness. When a productive family member first falls sick through AIDS a depletion of household resources generally occurs (Ntozi, 1997). Children's nutritional status may fall as food available for consumption decreases. Children, particularly girls, may take on extra commitments including household duties, agricultural tasks, and caring responsibilities involving cleaning, feeding, and administering medicine to their relatives (Bourdillon, 1999; Danziger, 1994; Robson, 2000; Robson and Ansell, 2000). Caring duties can place a heavy emotional burden on children and an increase in duties may disrupt or terminate their education (Grainger et al, 2001; Kamali et al, 1996). The stigma associated with AIDS can also cause problems for children left behind (Webb, 1997). Orphaned children commonly suffer anxiety and depression (Pivnick and Villegas, 2000), which is sometimes inaccurately diagnosed as children are not considered to suffer from emotional problems (Sengendo and Nambi, 1997). Although this demonstrates that the psychological, physical, and emotional burdens faced by AIDS-affected children have been well researched, missing from the analysis so far is an understanding of how children's geographical displacement increases the complexity of these AIDS-related impacts.

Since the beginning of the epidemic, AIDS and mobility have been closely associated. Early geographical literature focused mainly on the role of migration in the spread of the disease (Kearns, 1996), including between urban and rural areas and along trade routes (BakamaNume, 1996; Caldwell and Caldwell, 1993; Cliff and SmallmanRaynor, 1992; Larson, 1990; Wood, 1988). More recently, the focus has turned to the vulnerability of migrants to infection (Williams et al, 2002). Craddock (2000), for instance, calls for greater historical, social, and cultural contexualisation of the disease, embracing different spaces of vulnerability and the unequal power relations which put particular people at risk at certain times and places. The sociospatial context of the disease is important not only for understanding who is at risk and why, but also for understanding the impacts of the epidemic on people's lives. 
Relatively little attention has been given to the migration of those affected by AIDS. Despite this, household members, including children, have been found to move in response to the disease (Urassa et al, 2001). Household dissolution is based on cultural circumstances around property ownership, economic difficulties following the death of a household head, and the forming of new unions - for example, when widows remarry. Children may be involved in migration as part of household strategies or independently, particularly when households are no longer considered to be viable economic units. Children's migration is not only related to household dissolution but also employed by families as a coping mechanism (Ansell and van Blerk, 2004). This may include children being sent to work, to care for sick relatives, to live with other members of the extended family or foster parents, into institutional care, or going away through their own decision to seek survival on the streets (Ainsworth and Over, 1997; Baylies, 2001; Desmond et al, 2000).

After the death of a parent, children experience further upset and family disruption. If a father dies within a patrilineal society such as in Lesotho (and central and northern Malawi), children are expected to remain in the village of their father's male line. Traditionally they are still cared for by their mother, although she may be expected to marry her deceased husband's younger brother (Ali, 1998). Stigma associated with AIDS is eroding this practice, but a mother who refuses may be forced to leave the patrilineal home with her children (Cook et al, c. 2000). If the mother subsequently dies, children are generally cared for by their grandparents, which may involve returning to their village of origin. Within a matrilineal society, such as in southern Malawi, children traditionally grow up in the village of their mother's line. If the mother dies, the father will return to his own community and often have no further contact with his children (Cook et al, c. 2000). In both Lesotho and Malawi extended families are also spatially dispersed on account of high levels of labour migration (Crush et al, 1999; ILO, 1998; Sporton et al, 1999; Townsend, 1997). The sickness or death of an adult can precipitate the migration of his or her immediate family from the workplace or urban locality to a rural place of origin.

After the dissolution of a household due to parental death the decision for the care of children falls to a relative. In both patrilineal and matrilineal societies this is usually an uncle. Children may then move to live with their uncle or find themselves divided among relatives. Bourdillon (1998) found that a number of Zimbabwean orphans had siblings being cared for by relatives in distant places, suggesting that children may move between urban and rural areas - the effects of which are currently underresearched. Indeed, Foster et al (1995) touched on this in relation to urban areas but felt their study should also have included children moving to rural areas.

Despite high numbers of orphans in southern Africa, many extended families are still willing to take on extra children (Baylies, 2001). However, when family resources reach breaking point some children end up in institutional care. This removes children from the traditional and cultural values of their family and, although they may be well cared for physically, it can increase psychological distress such as isolation, loneliness, and depression (Munthali and Ali, 2000). To counteract this, some governments are trying to establish systems of fostering outside the extended family to help cope with the sheer intensity of the orphan problem, although this is still overburdened (Bandawe and Louw, 1997). On a positive note the principle care of orphans in extended families may be strengthening the central role of the family and clan in urban areas (Foster et al, 1995).

The reduced ability of some AIDS-affected households to provide care and support for children increases their vulnerability and poverty (Bourdillon, 1999; Cohen, 2000). 
Although many cope well after the death of their parents and are supported by their families and communities, deepening poverty can result in foster ${ }^{(1)}$ children being more likely to drop out of school, engage in paid and unpaid work, and suffer abuse (UNAIDS, 1999; Urassa et al, 1997). This may be exacerbated where great distances exist between extended family members, inhibiting close ties to other household units (Foster et al, 1997a). In an increasing number of cases, inadequate care is resulting in children taking to the streets to earn a living (Bourdillon, 1999; Human Rights Watch, 2001).

\section{The research}

The research we present in this paper was conducted in Malawi and Lesotho with young migrants between May and October 2001. Both countries have high levels of internal and external migration and both have been affected by HIV/AIDS. Currently, the estimated prevalence rates for the adult populations are $14.2 \%$ and $28.9 \%$, respectively, a fraction lower than at the time of the research (UNAIDS, 2004). Around $14 \%$ of children in Malawi and $19 \%$ in Lesotho are orphans (13\% and 14\%, respectively, in 2001) (UNAIDS, UNICEF, USAID, 2004). Malawi has a relatively long history of the pandemic, whereas the high incidence of the disease in Lesotho is a more recent phenomenon, with the full impact on children of adult deaths yet to be felt. The two settings allowed us to examine diverse situations. In both countries one urban and one rural community were selected to explore a wider range of experiences. The locations were selected after consultation with local academics and government education officials.

In Malawi the urban location of Ndirande, a low-income township in Blantyre (the main commercial centre), was selected because of its large transient population who have moved here to seek employment in the city. In contrast, the Mpando village area, located in Thyolo district in the south of the country, has a much less mobile population, although migration into and out of the area still takes place. Mpando is located in a tea-growing area, and therefore employment-related migration is not uncommon. In recent years migration has also occurred as a result of flooding in the region. The locations selected in Lesotho also accommodate relatively transient populations. The capital city, Maseru, is located in the Lesotho lowlands and receives migrants from the rural areas. The rural location, Tlali, is located approximately $60 \mathrm{~km}$ from Maseru, in the foothills of the Maluti Mountains. The local economy is based on a combination of subsistence agriculture and remittances from labour migration, particularly cross-border migration to South Africa's mines. People also move into the area from more isolated highland areas and from villages, in search of paid employment in the city.

In order to capture a full understanding of the varied migration experiences and adaptations faced by children who move within the context of AIDS, we adopted a children-centred multimethod approach to the research. This was based on the premise that children are competent commentators on their own lives (Holloway and Valentine, $2000 \mathrm{~b}$ ), and that therefore it is important to understand the impacts of migration from their perspectives. Children were accessed through schools in each community and were aged between 10 and 17 years. ${ }^{(2)}$

(1) This refers to fostering in its widest meaning, including any children cared for by adults other than their birth parent(s).

(2) It was decided to access children through schools because the majority of children in both Malawi and Lesotho attend school. Malawi offers free primary education and this is also being introduced in Lesotho on a rolling basis, although children do have to provide their own uniforms. However, we do acknowledge that some children are still out of school and therefore out-of-school children and street children also participated, identified through discussions with community leaders. 
We distributed a questionnaire to 822 children as a result of 'idea-generating' discussions on migration and on what it means to move house. Children in Lesotho were involved in drafting the questionnaire after an initial pilot. The appropriateness of using questionnaires in work with children has been widely discussed (Boyden and Ennew, 1997). We used the questionnaire as an exploratory tool for identifying children who had experience of migration (which we defined in broad terms as having moved to live in another house for a period of a month or more) and of sickness or death among close relatives. Children were asked for general information regarding whether children had moved, why they had moved, the number of times they moved, where they had moved from, and who they lived with both before and after migrating. We also asked whether other children had moved into their households, and the reasons for such moves. We further requested general family information, including whether their parents were alive and still caring for them. It is not ethically or practically possible to ask children directly about AIDS as a cause of death in their families: the stigma surrounding HIV/AIDS is such that deaths of relatives are almost never attributed to this cause. Chronic sickness and death were used as proxies, on the basis that approximately two thirds of orphans in Lesotho and Malawi have lost parents to AIDS (Hunter and Williamson, 2000b). On the backs of the questionnaires, the children were given the opportunity to draw or write about migration in order to express their thoughts and ideas on the subject. They were invited to talk to us about their drawings and any written explanations were translated.

From the 822 questionnaire respondents, 226 children who, according to their questionnaire responses, may have experienced AIDS-related migration were asked to participate in more detailed qualitative research. These were children who had moved home and had experienced sickness or death among close relatives, or who had had other children move into their homes in association with the sickness or death of a relative. As will be explained later, the causal relationship between AIDS and migration is seldom straightforward. This could be identified only by using qualitative methods. The use of focus-group discussions, migration storyboards, and migration mapping allowed the children to take some control of the research and to express freely detailed opinions. We involved all 226 children in focus-group discussions, which were held in local languages with the help of an interpreter. They were recorded and subsequently transcribed and translated into English. The children mediated the discussion through their management of the tape recorder (Young and Barrett, 2001), allowing them to 'own' the discussion and to remove the focus from ourselves. This was particularly important in light of the unequal power relations between the children and ourselves based on differences of age and race.

As a result of the discussions we invited fifty children for whom the relationship between AIDS and migration was particularly evident to draw storyboards and to map children's migration patterns in their communities. In both activities children worked independently from the researchers and later discussed their storyboards and maps in detail through a translator. The storyboards comprised a series of pictures representing important events in children's migration histories and assisted us to elicit detailed

\section{(2) continued}

The age of majority is difficult to determine in southern Africa given the different legal and cultural definitions. Cultural definitions vary according to ethnic group and may be related to marriage, initiation, or other traditional practice. In this case, as the research involved children in more than one country and of more than one ethnic background, the United Nations definition was used. A lower age limit of 10 years was put in place as it was necessary for children to be old enough to remember their migration experiences. Relying on children's memories of migration inevitably excludes migrations undertaken at a very early age. Although we acknowledge that younger children also participate in AIDS-related migration, the findings discussed in this paper relate mainly to migration taking place between the ages of 5 and 15 years. 
narratives of individual experiences. The mapping exercise involved small groups discussing where children move to when leaving the area, where they come from when moving into the area, and the reasons for these movements. The places were marked by the children on a map of the country and the reasons for each migration were recorded separately. In addition, to extend the range of migration stories, focusgroup discussions were also conducted with thirty-eight out-of-school children, twenty children residing in care homes, and thirteen street children. Eight of the street children and seven of the out-of-school children also drew migration storyboards.

Last, for purposes of triangulation, we conducted interviews with guardians and with key informants. Ten guardians from each community discussed with us their experiences of receiving young migrants into their homes.

\section{Children's migration in Malawi and Lesotho: the extent, nature, and causes}

Through the course of their lives, substantial numbers of children in both Malawi and Lesotho move between places of residence for different reasons, both with, and independently from, their parents. Close to half of the questionnaire respondents in Lesotho and more than half in Malawi reported having moved house (table 1). The larger numbers in Malawi may relate to that country's longer history of AIDS, which means that more children were affected longer ago than in Lesotho, where the number of orphans began to rise sharply only in the late 1990s (UNAIDS, UNICEF, USAID, 2004). Therefore, in Lesotho, orphans remain younger than our target age group and are also less likely to have experienced migration. However, we believe the actual numbers of migrants in both countries are significantly higher than reported in the questionnaires as some children did not view movements between households of the extended family as migration, regardless of the distance travelled or the length of time spent there. The qualitative research revealed that this extended-family migration accounted for a large proportion of children's migration activities, and that migration was underreported through the questionnaire.

Table 1. Percentage of children who have moved, and moved more than once in Lesotho and Malawi.

\begin{tabular}{|c|c|c|c|c|c|c|}
\hline & \multicolumn{3}{|l|}{ Lesotho } & \multicolumn{3}{|l|}{ Malawi } \\
\hline & Maseru & Tlali & total & Ndirande & Mpando & total \\
\hline Moved & 50 & 31 & 41 & 58 & 58 & 58 \\
\hline Moved more than once & 25.2 & 12 & 18.6 & 36 & 37 & 36.5 \\
\hline$N$ & 201 & 195 & 396 & 224 & 187 & 411 \\
\hline
\end{tabular}

A large proportion of those who indicated being involved in migration reported having moved more than once (table 1), illustrating that migration is not always permanent and may involve multiple moves. These longitudinal patterns were further illuminated through the migration storyboards, which indicated the existence of both cyclical and sequential migration patterns related to sickness and death. In most instances cyclical migration was undertaken when children moved to help relatives or to receive care, and was intensified when families were afflicted by sickness and death among the adult members (Young and Ansell, 2003). Linear migration was more often undertaken when initial migrations failed, either because the receiving household was unable to support incoming children financially or emotionally or because a change in circumstances reduced the economic viability of the household to a point at which it was unable to function without sending members elsewhere (Ansell and van Blerk, 2004). 
Migration experiences also varied between locations. Table 2 shows that more children in the urban settings of Ndirande and Maseru had moved within the local area $^{(3)}$ compared with the rural locations. In both Mpando and Tlali children indicated having moved from further afield. Although in this paper we focus primarily on the experiences of children undertaking longer distance migration (from another village or city), many of the issues discussed also apply to children moving within their local area, many of whom reported the unfamiliarity of their new environments. Of those children who moved over longer distances, more migrated to rural than to urban areas (although this excludes street children), which supports the contention that many children return to their rural village of origin after the sickness or death of a parent (interview, Dr Kaluwa, National AIDS Control Programme, Malawi).

Table 2. Percentage of children for each migration type in Lesotho and Malawi.

\begin{tabular}{|c|c|c|c|c|}
\hline \multirow[t]{2}{*}{ Migration type } & \multicolumn{2}{|l|}{ Lesotho } & \multicolumn{2}{|l|}{ Malawi } \\
\hline & Maseru & Tlali & Ndirande & Mpando \\
\hline Localised & 43.2 & 13.5 & 79.3 & 17.3 \\
\hline Urban to rural & - & 41.3 & - & 26.4 \\
\hline Rural to urban & 39.8 & - & 16.0 & - \\
\hline Rural to rural & - & 43.2 & - & 55.4 \\
\hline Urban to urban & 12.8 & - & 3.9 & - \\
\hline Another country & 4.2 & 2.0 & 0.8 & 0.9 \\
\hline$N$ & 97 & 62 & 130 & 110 \\
\hline
\end{tabular}

The mapping exercise added further information concerning places children moved between. In Tlali, Lesotho, children's inward migration was reportedly from the highlands or nearby villages. Parental death featured highly among perceived reasons for children moving into the village, whereas most children moving out of the village did so for schooling. Children moving into Maseru came from a greater variety of places including distant rural villages and regional towns. A few children moved out of the capital, we were told, generally to help relatives in rural areas. Those moving in came because their guardians had passed away or their parents had come in search of work. In Malawi children moving into Ndirande came from regional towns. Those who left the city reportedly moved to other towns or cities and did so because of parental death, schooling, or lack of parental employment opportunities. Those moving into Mpando came from other rural villages in the south, mostly because of flooding. Those moving out of the area moved either to the tea and tobacco estates in the north or into urban areas in search of employment. In both cases parental death was also mentioned although it was not reported as the most common reason for migration.

The questionnaire revealed a plethora of reasons for moving house, including the death or illness of a parent or guardian (table 3, see over). It was not, however, a reliable tool for determining the underlying causes for migration: in many instances the reason cited was the final trigger for movement related to a more complex underlying cause. Some migration was clearly not AIDS-related, but the focus groups revealed that migration was often a secondary outcome of sickness and death affecting a household. ${ }^{(4)}$ Numerous children had, for instance, moved home not because of the

(3) Here local area refers to the area children are familiar with. This generally means their immediate village area or subsection of a township within the urban locations.

(4) Often children do not know what their parents died of although they can describe the symptoms. Many children referred to their parents death as TB or as something in the chest (Lesotho), as a stitch or a headache: phrases often used as synonyms for AIDS. 
Table 3. Percentage of children who have moved for different reasons in Lesotho and Malawi.

\begin{tabular}{lccc}
\hline Reason & Lesotho & Malawi & Total \\
\hline Housing issues & 22.3 & 34.8 & 28.6 \\
Conflict or unsafe & 28.1 & 11.9 & 20.0 \\
Employment & 4.3 & 22.9 & 13.6 \\
Sickness or death & 5.0 & 15.3 & 10.2 \\
To provide help & 5.0 & 7.7 & 6.4 \\
School & 10.8 & 1.3 & 6.1 \\
Witchcraft & 2.9 & 3.0 & 3.0 \\
Agriculture & 1.4 & 3.0 & 2.2 \\
To be cared for & 2.9 & 0 & 1.5 \\
Environment & 1.4 & 0 & 0.7 \\
Other & 15.8 & 5.1 & 10.5 \\
$N$ & 139 & 235 & 374 \\
& & & \\
\hline
\end{tabular}

absence of a carer but because a parent became unemployed (because he or she was sick), because there was no money for rent (as a result of the death of a wage earner), or because their guardian was evicted by her in-laws (when her husband died). Children sometimes related their migration to inability to pay school fees, family conflict, or employment reasons, which were later revealed to be consequences of parental sickness or death. Other children moved to care for sick relatives in other households. Substantial numbers of children, $30 \%$ in Malawi and 19\% in Lesotho, also had relatives who had moved to live with them because of sickness or death either in their immediate family or in the receiving household.

Many children, then, moved as a response to family sickness or death. The qualitative research uncovered three areas of children's lives that were particularly affected as a result of migration. These were social, educational, and labour aspects. All migrant children are affected in these aspects of their lives, but where migration was related to AIDS the negative impacts are exacerbated. Equally, the effects of sickness and death on children's family circumstances were compounded by the impacts of migration. We will discuss each of the three areas of impact, before drawing to a conclusion regarding the implications for both migration research and children's geographies.

\section{Changing places: understanding the consequences of children's migration in the context of AIDS in southern Africa}

The social implications of migration

"The problems are when someone arrives at a new place they feel like they don't know themselves and they don't get used to the new place and miss their old one." Maseru boys, focus group 6

Developing a sense of belonging and place attachment is often associated with being rooted in society through social and spatial interactions (Gustafson, 2001). Moving to a new place can be disruptive for children for a range of reasons. Some children experience spatial disorientation as they find themselves in an unfamiliar environment. The children in this research illustrated how their social identity was disrupted through migration because they did not know the layout of their new town or village, which made them feel out of place. 
"It takes a while for you to get used to the new place. You don't know where to get water. I didn't know where to find the toilets and I didn't know where the shops were" (Tlali girls, focus group 6).

Not all of the migrant children experienced distress at being in a new environment. The children who were most disoriented were those who moved either after the death of a parent or as a wider family coping strategy to deal with the sickness of adult members. Those who related positively to their migration experiences had moved for other reasons including employment seeking or to access better education and living environments. Whether their migration was independent or as part of a family, these children's experiences were encased within a secure family environment, which made them less stressful. This illustrates the importance of social relationships in establishing a sense of belonging.

Pivnick and Villegas (2000) found that children affected by AIDS had a poor spatial understanding of their surroundings, which was related to "a social void, [a lack of] a cohesive space in which one is located as a member of a stable family a neighbourhood or a community" (page 109). The implications of AIDS for children's lives can be particularly stressful and include emotional distress, anxiety, and depression as a result of the sickness or death of a parent (Pivnick and Villegas, 2000). These psychosocial impacts are compounded by other factors such as declining household income, hunger, poor health status, sibling separation, and greater family responsibilities (Grainger et al, 2001; UNAIDS, UNICEF, USAID, 2002). Although some research has mentioned migration as a way in which AIDS impacts on children (Grainger et al, 2001; Urassa et al, 1997), the AIDS literature fails to demonstrate how this reinforces other social impacts. This research suggests that for AIDS-affected children the negative implications of isolation, anxiety, depression, and poverty are exacerbated by migration. In part this is related to the (often) unexpected nature of AIDS-related migration. The qualitative research revealed that because of the stigma associated with AIDS children are not aware of the circumstances surrounding parental sickness and death. The truth is hidden from children, possibly altruistically to protect them, but this means they are largely excluded from the discussions relating to their subsequent migration.

Disruption to friendship groups was particularly problematic. Friends form an important part of children's social activity and are crucial to their identity formation. Those outside such intragenerational contact find themselves in a weakened position (Candappa and Egharevba, 2002). In both Malawi and Lesotho children frequently mentioned missing their friends as one of the negative aspects of moving and commented on the isolation felt prior to establishing new groups of friends.

"[The problem with migration is] arriving at a new place, and meeting people you don't know because you've left the ones you know behind, and you can't play with anybody because you don't know them" (Tlali girls, focus group 2).

Losing access to this social grouping isolates children and increasingly confines them to home spaces, reducing their familiar social territory. Once again, the consequences can be worse for those affected by AIDS. The traumatic event of losing a parent, for instance, makes integrating into a new community more difficult for children. Guardians also expressed how children's state of mind made it difficult for them to adapt easily to their new lives.

"The children felt pity for themselves all the time after their parents died... . I could see that they were different and had changed. They were sad and didn't like going to play with [new] friends" (Ndirande aunt).

After the death of a parent, many children are separated not only from friends, but also from siblings. In order to share the burden of care, children may be dispersed 
between family households, meaning they move between places and simultaneously lose their family and friendship networks. The absence of strong social ties and attach ents between children, their caregivers, and friendship groups hinders the construction of children's social space. In order for children to belong to their new place, these bonds need to be restored and developed.

The nature of AIDS-related migration, however, often makes repairing such bonds difficult. As new carers themselves fall sick or as their ability to provide financial assistance deteriorates, children engage in repeated or sequential moves. Chipi's ${ }^{(5)}$ story illustrates the isolation felt through sequential migration, particularly in the context of the AIDS pandemic.

"It used to be nice to have both parents around. I received enough care and had everything I wanted. We lived in Zomba barracks because my father was a soldier. When my father died we went back to my mother's village.... We didn't have enough of everything like food.... It wasn't nice, there was only one child. The rest of the village had died of AIDS. This happened in my home village and it leaves the old ones and the young ones. I stayed there for 2 years and then my father's brother came took me to Ndirande [Blantyre].... I was upset leaving because I wanted to live with my family... . Although my uncle gives me everything sometimes I get bored because I don't see my relatives and I'd like to visit them" (Chipi, aged 17, storyboard).

Arriving in a new community as an orphan is further problematic because of the increasing association between orphanhood and AIDS, which stigmatises children and makes integration into community life increasingly difficult (Webb, 1997). Particularly in Lesotho, children talked of being teased and ridiculed by villagers. Stigma appeared to be less of a problem in Malawi and guardians talked more openly about the effects of the disease on their community. The long-standing nature of the epidemic, coupled with high numbers of orphans and greater community awareness, may have lessened the impact of stigma by association.

"When you get to the lines [rented accommodation] you find that people there already dislike you, saying you children have mucus" (Maseru boys, focus group 4).

"When they [young migrants] are playing and they get into a fight, the [other] children say 'get lost you don't even have parents'" (Maseru grandmother).

Sharing resources with other children in the community was mentioned as a way of making new friends; however, this was hindered by poverty, which is exacerbated by AIDS (Ntozi, 1997), again illustrating how children's normal mechanisms for coping with migration are disrupted by the effects of AIDS. This was clearly an obstacle for children fitting into new environments.

"It's difficult for you to have a friend at school if you don't bring money to use at break time because friends don't like to go around with someone who has no money" (Ndirande boys, focus group 4).

Fitting in can be problematic for any child migrants, but is especially important for children who have already experienced family loss or separation. The associated trauma that manifests itself in withdrawal and shyness or undesirable behaviour such as truancy (Grainger et al, 2001; Orellana et al, 2001) was further compounded where children had to migrate. Boys, and street children in particular, described getting involved in activities such as smoking and drinking alcohol as a way of gaining acceptance and of satisfying their need for belonging. This resonates with Ali's (1998) findings where new guardians reported having to deal with behavioural problems of children conscripted to their care.

(5) To protect children's identities all names used are pseudonyms. 
"The people who live in my new area are very mischievous, some smoke, some drink and they influence others to do all these things.... I didn't use to smoke at my old place but when I got here I got attracted to this new behaviour and I started smoking" (Maseru boys, focus group 4).

"Also when someone comes from the village, he sees what his friends do and he copies their behaviour" (Blantyre street kids, focus group 1).

The feeling of abandonment that can follow parental death can be particularly difficult for children who migrate. Children moving beyond their local area also lose support from familiar community members and from familiar environments, making the need for acceptance all the more immediate. In Mpando the village headman resonated this sentiment, stating that children who move are more likely to develop strategies for gaining acceptance - which can result in the adoption of bad behaviours.

"Mostly they move within the area when their parents die, although some come from outside. It's better for children to move from one village to another rather than going outside as they may change and adopt bad behaviours" (Mpando village headman).

While some children describe migration as a positive experience, this is tempered by the context within which it takes place. For those affected by AIDS the more negative aspects can be exacerbated. The isolation children feel as a result of the disruption associated with losing family support networks and friendship groups because of moving can compound the trauma associated with losing a parent or of having to care for a sick relative. Children arguably experience the social and psychological impacts of AIDS more acutely when migration is part of the solution implemented for their care. Repeated migration, experienced by many as a result of AIDS, further disrupts the development of new social networks and social ties in the receiving community, which may also be hindered through stigmatisation by the association of orphanhood and of long-term sickness with AIDS. Given the interconnectedness of AIDS and migration in influencing children's social relations within a new community, there is a need for greater contextualisation in migration research and for recognition of the role children perform within migration.

\section{Educational disruption}

Schooling is an important aspect of most children's lives and impacts on their migration experiences in complex ways. Although the literature discussing children's migration is sparse, education has featured prominently in a number of studies as a key catalyst for promoting positive migration experiences (Dobson and Stillwell, 2000; Orellana et al, 2001). These studies demonstrate how important migration decisions within families are sometimes taken as a response to providing the best educational facilities for children. The research reported here to a certain extent supports this, with a number of children reporting that migration had enabled them to attend school, or to access a better school. In some cases, such migration was an indirect consequence of AIDS - where the disease had deprived their household of a wage earner, children were commonly taken to live with a relative who could afford their school fees. This usually entailed moving from a rural to an urban area.

"I moved to Ndirande from Thyolo... . I was very happy in Ndirande as I now had a good life and I am also going to a good school here now. I am learning new subjects like English and maths so my future is better" (Ndriande girl, aged 14, storyboard).

"I moved to live in Maseru with my sister because only she could afford to pay the fees to send me to school" (Maseru boy, aged 15, storyboard). 
The emphasis of this paper is on how (AIDS-related) migration affects children's experiences of education, rather than on education as a reason for migration. In many respects the disruption caused to education by migration affects all migrant children, but AIDS-related issues can compound the problems children face.

Within the AIDS literature studies have shown that children's education is often disrupted or terminated as a result of the AIDS affliction of family members. The cost of care and loss of labour and income often mean children's families cannot afford to pay school fees, or that children are withdrawn to engage in other tasks to support the family (Foster et al, 1997b; Kamali et al, 1996). Urassa et al (1997) note that orphans and foster children are disproportionately represented among those out of school.

Guardians in both Malawi and Lesotho spoke of education as important and stressed that they tried to ensure all children in their care were able to attend school, although increased poverty from caring for extra children sometimes meant aged grandparents took on income-generating tasks in order to assist their grandchildren. Further, the recent emphasis on increasing primary enrollment throughout sub-Saharan Africa has resulted in reduced fees and in more children from very poor households being able to attend. ${ }^{(6)}$ Despite this, children mentioned disruption to their education, related both to poverty and to changing schools, as a consequence of their migration. Migrating within the context of AIDS creates situations where education becomes secondary to family coping mechanisms rather than a major consideration.

In some instances, moving to live with relatives who could not afford to pay school fees resulted in children's education being disrupted. For example, in Malawi, when David's mother died his father remarried. Although David's father was able to provide for him, mistreatment by his stepmother, who favoured her own children, resulted in David leaving the household to live with his uncle and aunt in Mpando. Although this was generally a positive move:

"the only problem is that he is lacking money to pay for school. He was supposed to go into form 4 but he is lacking the funds so he is just staying here" (Mpando aunt).

Dropping out of school was a direct result of the move because David's father stopped paying his fees and because his relatives, although fairly wealthy in the village, have too many children and foster children to afford secondary school fees.

Changing place also resulted in some young people changing schools. The change can sometimes be dramatic. One Ndirande aunt explained how the children in her care used to attend a private fee-paying school. They had to leave the school when they moved to live with their aunt as the result of the sickness and death of their breadwinning parent. They now attend the local primary school and find the difference in lessons problematic.

"When they were at home they used to go to private school but when they came here they went to the local school. They didn't like having to change schools and the differences in the lessons. They didn't like that" (Ndirande aunt).

Other young migrants raised similar issues including differences in lessons, teachers, subject content, and difficulties associated with getting used to a new school. The discussion groups in Ndirande, Malawi, referred to the size of the school: it is host to nearly nine thousand pupils and new children often get lost, unable to find their class. Although such problems confront all migrant children, as with the social disruption described in the previous section the impacts on those moving in relation to AIDS can be worse because of the social isolation associated with losing a close relative.

(6) Primary education is currently free in Lesotho only for standards one and two (NGO Coalition for the Rights of the Child, 2000). On top of fees for subsequent classes, schools charge pupils for educational materials and to pay the salaries of supplementary private teachers (interview, head teacher, St John's Tlali Primary School). 
Moving to a new place can also make enrolment difficult. AIDS-related migration often occurs at inconvenient times within the school calendar because relatives and children are sometimes ill prepared for migration, and instead hope that sick relatives will recover. This may result in delayed enrolment. Some children who moved in the middle of the year were unable to attend school, even if their relatives could provide uniforms and books, because the places had already been filled. In the context of children's education this can slow the process of integration into a new school because of the need for transfer letters and references.

"For kids it's difficult if you move to a new school because there might be no vacant place for you to enrol there. So you go to another school and the same thing might happen. Time may pass and then it's difficult to catch up if you have no friends to give you the notes" (Ndirande boys, focus group 4).

"I was denied a new place in school because I had no transfer letter so I had to go back and get a letter before I could start school" (Ndirande boy, aged 14, storyboard).

However, parental death reduces the support available to children, who find themselves faced with difficult circumstances. The emotional trauma associated with the impact of AIDS is compounded through migration as changes occur in both family and community life, including changes in education. Guardians illustrated how the psychosocial impacts of AIDS on children intensified through migration, led to greater educational disruption.

"The child changed schools because of the move and this affected her schoolwork.

It became very poor and the teachers complained that the move and her mother's death seems to have put a lot of strain on her academic work" (Maseru uncle).

"There are two of them who dropped out of school when they came here looking for food in the streets, picking out of the dustbin. But I had to intervene and say that I would go to the police if they continued with that life. So they tried to go to school but most of the time they don't go... This was a reaction to their parents' death.... When the parents died the relatives of the father's side didn't want to take them in" (Ndirande grandmother).

In southern Africa, where crossborder migration is common, moving schools sometimes takes place across borders, particularly in Lesotho where proximity to South Africa results in migration of mine workers, families, and professionals out of the country (Crush et al, 1999). Tsepho's storyboard reveals how he had been brought up in South Africa, where his father worked for one of the mining companies. When his father fell sick he was retrenched and the family moved back to their Lesotho village, where Tsepho's father subsequently died. In his storyboard Tsepho identifies some of the problems and difficulties he encountered adapting to his rural home.

"Coming back from Jo'burg wasn't pleasant as we were coming back to our first small house. My father died two weeks after we got home from TB.... It was difficult adapting to school in Tlali as in Jo'burg there were lots of races and I learned in Setswana but here I had to learn Sesotho and all the different spellings" (Tlali boy, aged 13, storyboard).

Language was considered a major issue for children who moved across borders. Roderick moved from Malawi to Mozambique after the death of his mother, which created problems at school as he did not understand the lessons. However, for him the situation was rectified when he returned to Malawi to live with his grandmother, a second stage in his migration story. 
“The problem was that I couldn't understand the lessons in Mozambican schools while at our school here in Malawi I am able to understand any kind of lesson" (Mpando boys, focus group 5).

The migration-related educational experiences of children placed in institutional care are sometimes different. Some orphanages have their own schools, reducing children's everyday social and spatial range as they find themselves almost exclusively associating with other orphans. Others receive additional benefits as some institutions have access to a greater range of educational and material resources. This is particularly the case where orphanages are funded by international donations. Although normally viewed as a positive benefit to the few who are placed in this situation, where education is provided within the local community children are sometimes actively discriminated against because they are seen to be receiving special care. The focusgroup discussion at a children's home in Blantyre highlighted the teasing some children received from their teachers because they were residing in an orphanage.

"when I was in standard 7 the teachers said a lot of bad things about us because they said we stay here [orphanage] so they took us as living a high standard of life" (Malawi orphanage, focus group).

The context within which children migrate affects their educational experience. Often education is a positive reason for moving or at the very least is given careful consideration during the decisionmaking process. However, AIDS-related migration appears to increase the complexity and disruption of the educational difficulties faced by children. Education may become secondary to the emotional, economic, and social effects of sickness or death in the family, and basic needs assistance or cultural obligation are usually the criteria used by families when taking migration decisions. The result is a complex set of problems that children are expected to deal with while adapting to the new social space of the school they find themselves in or are excluded from. This research therefore illustrates the particular problems migration poses for children affected by AIDS, which is little considered currently within the AIDS literature.

\section{Children's adaptation to place-related work activities}

Most children in Africa over the age of about 7 years engage in some forms of paid or unpaid work. Migration impacts on children's experiences of work, not least because the kinds of work expected of children differ from place to place. Children also engage in labour migration, a situation that has received some attention in the literature pertaining to children's migration. Although this is not always positive and is often related to poverty within families, children's autonomy in labour-migration decisions is apparent (Iversen, 2002; Young, 2004).

Where children move in the context of AIDS the effects on work activities are likely to be particularly marked. The AIDS literature suggests that households tend to increase children's involvement in work activities, both paid and unpaid, after the sickness or death of a family breadwinner (Bourdillon, 1999; Danziger, 1994; Robson, 2000; Robson and Ansell, 2000). Children migrating as a result of AIDS may be expected to undertake more work than children moving in other circumstances, and in some instances AIDS-related migration is for the explicit purpose of work - such as in cases where children are sent to care for a sick relative (Ansell and van Blerk, 2004). Where migration is implemented as a strategy for dealing with the impacts of AIDS the work activities that children are expected to engage in can be very different from what they are used to and can involve negotiating unfamiliar territory.

Moving to a new place may mean earning for personal survival (as was the case for street children) or taking on extra chores. This latter point was more often experienced 
when children had migrated to live with grandparents or sick relatives, where they engaged in household chores, income generation, and caring duties. The following examples illustrate the types of activities young migrants engaged in. The difference in duties is especially great when children move from urban to rural locations (a situation that is particularly common where migration is related to AIDS).

\section{Urban to rural migration}

Rapid rural to urban migration in southern Africa in recent years means that many city dwellers are fairly recent migrants who have moved in search of employment (ILO, 1998). As previously noted, after the sickness or death of a parent, children often have to return to rural areas to receive care from relatives within the extended family, usually grandparents. It is the work activities associated with this type of move that children find the most difficult to cope with, and the most distressing, as the work is generally more arduous. Children who had never worked in the fields before were suddenly given unfamiliar tasks to undertake, in some instances without instructions. The extract below taken from Ruth's storyboard illustrates in detail the problems faced by children who are expected to develop new ways of life after moving to live with relatives. Although it is clear that children are resilient and adapt well to their new circumstances, as Ruth's cousin did, migration as a result of parental death can be a very stressful experience.

"When [my cousin's] parents died he came to live with us... he had never worked before.... We used to tease him because he wouldn't help. We wouldn't give him any food when he didn't work, only when he started working.... My father used to mould bricks for a living and he used to teach us those skills but my cousin didn't like it and wouldn't do it .... [Also] when he was given the hoe [to work in the fields] he just cried. This made me angry and I used to shout at him.... He had never worked in a field before so he found it really difficult.... After some time he got used to this and living with us and he even began to mould bricks on his own" (Ndirande girl, aged 13, storyboard).

In Lesotho, boys had particular problems with herding animals after urban to rural migration. Many found the work boring and were teased by other children. The integration of work and play was particularly problematic. Herd boys often engage in stick fights and other games associated with their work. Children unfamiliar with herding, who do not know the associated games, become isolated in their new environment through exclusion from these play activities, compounding the social isolation faced by AIDS-related child migrants described above.

"When I first moved from Maseru ... I was told to go and herd and I didn't know how to herd. When I got there, one of the boys challenged me to a stick fight. But because I wasn't good at it I was beaten so I took some stones and threw them at these boys" (Maseru boys, focus group 9).

\section{Rural to urban migration}

Adapting to urban life is considered easier as children's involvement in household chores is much reduced (interview, Me Mohapeloa, Director of Youth Affairs, Ministry of Environment, Gender, and Youth, Lesotho). Young migrants talked less of adapting to work activities and more concerning the positive differences about living in urban areas, such as better food, electricity, and motor vehicles. In relation to chores, however, the discussions highlighted how they missed their rural activities and village life, which demonstrates that adaptations still have to be made. As work activities are confined more to the home and immediate environment, it is unsurprising that moving to the city reduced children's spatial freedom. 
"Back in the village there was work for them to do but here they do less work like washing the clothes. When they came at first they still missed the village. Village life and town life is different so they couldn't just adjust to being here in town" (Ndirande grandmother).

"I enjoyed living in my old place, it was fun because I used to herd cattle. Now it's boring because there are no cows here" (Maseru boys, focus group 4).

Not all children who moved into urban areas as a consequence of AIDS-related migration entered a family environment. Children who moved onto the streets had a different experience adapting to work-related strategies. Street children's spatial freedom increased as they embarked on an independent lifestyle. However, as we noted earlier, in order to be accepted on the street and develop new social relationships, children engaged in very different behaviours. As a means of survival, and by being located in the street, these new social and spatial networks initiated young AIDS migrants into new labour activities. Begging, stealing, and assisting shoppers were activities which necessitated divergence from village life and were important strategies for remaining in new 'street-family' situations as food was shared between children.

"I ... steal from the woman who sells cigarettes. Maybe I don't have enough money for food .... [When did you start stealing?] After I came into town. I learnt from the people I found here" (Blantyre street kids, focus group 1).

"I ... look after white people's cars. When they give me money I buy food. I use some of it to buy glue but I also buy pap and meat" (Maseru street kids, focus group 1).

Migration within the context of AIDS creates very specific work experiences for children, which are again secondary to basic needs assistance. Rather than moving to engage in familiar work, children are expected to adapt to the place-related work activities of their new environments, often with little or no autonomy in the decision to engage in particular activities. Unlike much labour migration where children are often active participants in the decision to leave (Silvey, 2001), AIDS-related migration, between urban and rural environments in particular, results in an expectation that children will adapt and take on previously unfamiliar activities simply because of their surroundings.

This illustrates the importance of considering children's migration experiences in discussions around the impacts of AIDS on children. Although the literature highlights the increased involvement of children in labour activities where households are affected (Bourdillon, 1999; Danziger, 1994; Robson, 2000), this does not consider the ways in which the increased burden is impacted upon through migration. This research goes some way to identifying the particular issues this raises.

\section{Conclusion}

As the research discussed here demonstrates, children are engaged in migration activities and need to be brought to the forefront of migration-research agendas (Dobson and Stillwell, 2000). Such agendas should recognise the complexity of children's migrations, in particular how the impacts of large-scale social and economic processes (such as AIDS) influence (often unaccompanied) migration and the implications this has for children.

AIDS impacts on southern African children's experiences of migration in a number of ways. As a consequence of the pandemic, more children are migrating and children are migrating more often. In light of the recent calls for culturally informed migration research (Halfacree, 1995; McHugh, 2000), however, it is inadequate for research simply to assess the extent of children's migration and ensuing spatial patterns. Rather, there is a clear need to consider the implications of migration for children's social and 
spatial lives. Through the research we identified three aspects of children's lives which are particularly affected by the combination of AIDS and migration. In all cases the impacts of migration are produced in part through children's active engagement with their new circumstances.

First, psychosocial trauma and poverty coupled with migration were shown to influence children's abilities to adapt to new places and develop essential social relationships necessary for integration into community life. Second, educational disruption was more difficult for young AIDS migrants. Although households affected by AIDS may remove children from school to engage in other activities, migration also affects education in various ways, particularly in relation to changing schools and differences in language, curriculum, and teaching methods. Third, the research draws attention to the changing nature of young migrants' labour activities. Although many children take on extra chores when their families are afflicted by AIDS (Bourdillon, 1999; Danziger, 1994; Robson, 2000; Robson and Ansell, 2000), those who migrate, particularly between urban and rural areas, find themselves having to learn new skills in order to fulfil their daily duties.

These findings are wholly supportive of the literature arguing for greater contextualisation of migration in research (Lawson, 2000; McHugh, 2000). It is noteworthy that, although the migration experiences of children varied between social context (whether they were in or out of school, street children, or children residing in care homes, urban or rural, or from Malawi or Lesotho), experience of sickness and death among relatives was an equally important aspect of children's social context shaping their migration experiences. However, AIDS is not a simple contextual background for children's experience of migration, nor is it simply a trigger causing them to migrate. Rather, children's sociospatial experiences are coconstructed through the complex interaction of AIDS with migration. AIDS thus combines with migration with consequences for children that are worse than the impacts of migration on children in other circumstances. It does so in three ways. First, migration related to AIDS happens alongside other negative consequences of AIDS (such as dropping out of school). Second, the impacts of AIDS can exacerbate the impacts of migration (where, for instance, children who have lost parents or relatives to the epidemic are further socially isolated by moving away from their friends and siblings). Third, children's AIDSrelated migration can take forms that make it particularly problematic: it is more likely to be unaccompanied; may happen suddenly, leaving children unprepared and disrupting their education mid-year; it is also more likely to move them from urban to rural environments, in which they are ill prepared for work activities.

Finally, broadening the discussion to a wider theorisation of children's geographies, the research shows that the evident significance of migration for many children calls for geographers to recognise the spatiality of children's lives at a wider scale than has hitherto been examined. Whereas global processes have been shown to influence children's localised lives (Holloway and Valentine, 2000b; Katz, 1993), this research illustrates that the influence of large-scale processes such as AIDS can give rise to large-scale movements across space, which impact on children's lives. Migrant children are constantly negotiating new spatial territories as they move between different environments, and are actively engaged in creating geographies that traverse space and take place over long distances. Children's migration geographies in turn influence their day-to-day existence. We argue that the microgeographies of children who move are complexly constructed from a variety of experiences derived through children's interaction with different places. Moreover, children's microgeographies, in places they move to, will develop as their familiarity with each new environment is strengthened. Migration research also demonstrates the temporality of these geographies, 
adding a further dimension to the complexity of children's spatial lives. More work is needed on these transient geographies and on how children's identities shape, and are shaped by, their places of origin and new surroundings.

\section{References}

Ainsworth M, Over M, 1997 Confronting AIDS: Public Priorities in a Global Epidemic (Oxford University Press, New York)

Aitken S C, 2001 The Geographies of Young People (Routledge, London)

Ali S, 1998, "Community perceptions of orphan care in Malawi", paper presented at the Conference on Raising the Orphan generation, Pietermaritzburg, $9-12$ June, http:// synkronweb.aidsalliance.org/graphics/OVC/documents/0000222e00.pdf

Ansell N, van Blerk L, 2004, "Children's migration as a household/family strategy: coping with AIDS in southern Africa" Journal of Southern African Studies 30 673-690

BakamaNume B, 1996, "A geography of AIDS: spatial variation of AIDS infection in Uganda, 1987 - 1994", Department of Geography, Makerere University, Kampala

Bandawe C R, Louw J, 1997, "The experience of family foster care in Malawi: a preliminary investigation" Child Welfare $76535-547$

Baylies C, 2001, "Precarious futures: the new demography of AIDS in Africa, Africa's young majority: meanings, victims, actors", Centre of African Studies, University of Edinburgh, Edinburgh

Beazley H, 2000, "Street boys in Yogyakarta: social and spatial exclusion in the public spaces of the city", in A Companion to the City Eds G Bridge, S Watson (Blackwell, Oxford) pp 474-488

Bourdillon M F C, 1998, "Earn-and-learn: work for education in the Eastern Highlands of Zimbabwe", Workshop on Children, Harare; copy available from the author, Department of Sociology, University of Zimbabwe, Harare

Bourdillon M F C, 1999, "The next generation", Conference on AIDS, Livelihood and Social Change in Africa, Wageningen; copy available from the author, Department of Sociology, University of Zimbabwe, Harare

Boyden J, Ennew J (Eds), 1997 Children in Focus: A Manual for Participatory Research with Children Radda Barnen (Swedish Save the Children) SE-107 88 Stockholm

Caldwell J C, Caldwell P, 1993, "The nature and limits of the sub-Saharan African AIDS epidemic: evidence from geographic and other patterns" Population and Development Review 19817 - 848

Camacho A Z V, 1999, "Family, child labour and migration: child domestic workers in Metro Manila" Childhood 6(1) $57-73$

Candappa M, Egharevba I, 2002, "Negotiating boundaries: tensions within home and school life for refugee children", in Children, Home and School: Regulation, Autonomy or Connection? Ed. R Edwards (Routledge, London) pp $155-171$

Cliff A D, Smallman-Raynor M R, 1992, "The AIDS pandemic: global geographical patterns and local spatial processes" The Geographical Journal 158 182-198

Cohen D, 2000, "Poverty and HIV/AIDS in sub-Saharan Africa", Social Development and Poverty Elimination Division, United Nations Development Programme, http://www.undp.org/seped/ publications/poverty_HIV_SSA.pdf

Coldrey B M, 1999, “ “... a place to which idle vagrants may be sent': the first phase of children's migration during the 17th and 18th centuries" Children and Society $1332-47$

Cook P H, Ali S, Munthali A, c. 2000, "Starting from strengths: community care for orphaned children in Malawi", International Development Research Centre, http://web.uvic.ca/iicrd/ graphics/Malawi\%20Report_pdf

Craddock S, 2000, "Disease, social identity, and risk: rethinking the geography of AIDS" Transactions of the Institute of British Geographers, New Series 25 153-168

Crush J, Ulicki T, Tseane T, Jansen van Vuuren E, 1999 Undermining Labour: Migrancy and Sub-contracting in the South African Gold Mining Industry (Idasa, Cape Town)

Danziger R, 1994, "The social impact of HIV/AIDS in developing countries" Social Science and Medicine $39905-917$

Davin A, 1996 Growing Up Poor: Home, School and Street in London 1870 - 1914 (Rivers Oram Press, London)

Desmond C, Michael K, Gow J, 2000, "The hidden battle: HIV/AIDS in the household and community" South African Journal of International Affairs 7(2) 39-58

Dobson J, Stillwell J, 2000, "Changing home, changing school: towards a research agenda on child migration" Area $32395-401$ 
Findlay A M, Li F L N, 1997, "An auto-biographical approach to understanding migration: the case of Hong Kong emigrants" Area 29(1) 34-44

Findlay A M, Li F L N, 1999, "Methodological issues in researching migration" The Professional Geographer 51(1) $50-59$

Fontes M B, Hillis J, Wasek G K, 1998, "Children affected by AIDS in Brazil: estimates of the number of children at risk of being orphaned and displaced by AIDS in Brazil" Childhood 5 $345-363$

Foster G, Shakespeare R, Chinemana F, Jackson H, Gregson S, Marange C, Mashumba S, 1995, "Orphan prevalence and extended family care in a peri-urban community in Zimbabwe" AIDS Care 7(1) $3-17$

Foster G, Makufa C, Drew R, Kralovec E, 1997a, "Factors leading to the establishment of childheaded households: the case of Zimbabwe" Health Transition Review 7 Supplement 2, 155 - 168

Foster G, Makufa C, Drew R, Mashumba S, Kambeu S, 1997b, "Perceptions of children and community members concerning the circumstances of orphans in rural Zimbabwe" AIDS Care $9391-405$

Grainger C, Webb D, Elliott L, 2001 Children Affected by HIV/AIDS: Rights and Responsibilities in the Developing World Save the Children, 1 St. John's Lane, London EC1M 4AR

Gustafson P, 2001, "Roots and routes: exploring the relationship between place attachment and mobility" Environment and Behavior $33667-686$

Gutting D, 1996, "Narrative identity and residential history" Area 28482 - 490

Halfacree K H, 1995, "Household migration and the structuration of patriarchy: evidence from the USA" Progress in Human Geography 19159 - 182

Halfacree K H, Boyle P J, 1993, "The challenge facing migration research: the case for a biographical approach" Progress in Human Geography 17333 - 348

Holloway, S L, Valentine G (Eds), 2000a Children's Geographies: Playing, Living, Learning (Routledge, London)

Holloway S L, Valentine G, 2000b, "Spatiality and the new social studies of childhood" Sociology $34763-783$

Human Rights Watch, 2001, "Kenya: in the shadow of death: HIV/AIDS and children's rights in Kenya" Human Rights Watch 13(4A), http://www.hrw.org/reports/2001/kenya/kenya0701.PDF

Hunter S, Williamson J, 2000a, "Children on the brink: executive summary: updated estimates and recommendations for intervention" (USAID, Washington, DC)

Hunter S, Williamson J, 2000b, "Children on the brink: strategies to support a generation isolated by HIV/AIDS", USAID, Washington, DC

ILO, 1998, "Internal and external migration and youth unemployment in Lesotho", International Labour Organization, Maseru, Lesotho

Iversen V, 2002, "Autonomy in child labor migrants" World Development 30817 -834

Kamali A, Seeley J A, Nunn A J, Kengeya-Kayondo J F, Ruberantwari A, Mulder D W, 1996, "The orphan problem: experience of a sub-Saharan Africa rural population in the AIDS epidemic" AIDS Care $8509-515$

Kandel W, Kao G, 2001, “The impact of temporary labor migration on Mexican children's educational aspirations and performance" International Migration Review 35 1205-1231

Katz C, 1993, "Growing girls/closing circles: limits on the spaces of knowing in rural Sudan and United States cities", in Full Circles: Geographies of Women over the Life Course Eds C Katz, J Monk (Routledge, London) pp 88-106

Katz C, 1994, "Textures of global changes: eroding ecologies of childhood in New York and Sudan" Childhood $2103-110$

Kearns R A, 1996, "AIDS and medical geography: embracing the Other?" Progress in Human Geography $20123-131$

Kimane I, Mturi A J, 2001 Rapidly Assessing Children at Work in Lesotho. Volume 1: Context and Overview of Findings Government of Lesotho, MASERU, with financial assistance from UNICEF

Larson A, 1990, "Social epidemiology of Africa's AIDS epidemic" African Affairs 89 5-25

Lauby J, Stark O, 1988, "Individual migration as a family strategy: young women in the Philippines" Population Studies $\mathbf{4 2} 473$ - 486

Lawson V A, 2000, "Arguments within geographies of movement: the theoretical potential of migrants' stories" Progress in Human Geography 24173 - 189

McClure R, 1981 Coram's Children: The London Foundling Hospital in the Eighteenth Century (Yale University Press, New Haven, CT) 
McDowell C, de Haan A, 1997, "Migration and sustainable livelihoods: a critical review of the literature", WP 65, Institute of Development Studies, University of Sussex, Brighton, Sussex

McHugh K E, 2000, "Inside, outside, upside down, backward, forward, round and round: a case for ethnographic studies in migration" Progress in Human Geography $2471-89$

McKendrick J, 1999, "Multi-method research: an introduction to its application in population geography" The Professional Geographer 51(1) $40-49$

McKendrick J H, 2001, "Coming of age: rethinking the role of children in population studies" International Journal of Population Geography 7461 - 472

Massey D, 1998, “The spatial construction of youth cultures”, in Cool Places: Geographies of Youth Cultures Eds T Skelton, G Valentine (Routledge, London) pp 121 - 129

Matthews H, Limb M, Taylor M, 1999, "Reclaiming the street: the discourse of curfew" Environment and Planning A $311713-1730$

Matthews H, Taylor M, Percy-Smith B, Limb M, 2000, "The unacceptable flaneur: the shopping mall as a teenage hangout" Childhood $7279-294$

Munthali A C, Ali S, 2000, "Adaptive strategies and coping mechanisms: the effect of HIV/AIDS on the informal social security system in Malawi", Government of Malawi, National Economic Council, Lilongwe

NGO Coalition for the Rights of the Child, 2000, “'Etsa letsete la kamoso, netefatsa litokelo tsa ka': the state of children's rights in Lesotho/Boema ba litokelo tsa bana Lesotho", Save the Children, St. John's Lane, London EC1M 4AR

Ntozi J P M, 1997, "Effect of AIDS on children: the problem of orphans in Uganda" Health Transition Review 7 Supplement, $23-40$

Ogden P E, 1998, "Population geography" Progress in Human Geography 22105 - 114

Orellana M F, Thorne B, Chee A, Lam W S E, 2001, "Transnational childhoods: the participation of children in processes of family migration" Social Problems $48572-591$

Pivnick A, Villegas N, 2000, "Resilience and risk: childhood and uncertainty in the AIDS epidemic" Culture, Medicine and Psychiatry 24101 - 136

Potts D, 1995, "Shall we go home? Increasing urban poverty in African cities and migration processes" The Geographical Journal 161245 -264

Pribilsky J, 2001, "Nervios and 'modern childhood': migration and shifting contexts of child life in the Ecuadorian Andes" Childhood $8251-273$

Punch S, 2000, "Children's strategies for creating playspaces: negotiating independence in rural Bolivia”, in Children's Geographies: Playing, Living, Learning Eds S L Holloway, G Valentine (Routledge, London) pp $48-62$

Robson E, 2000, "Invisible carers: young people in Zimbabwe's home-based healthcare" Area 32(1) $59-70$

Robson E, Ansell N, 2000, "Young carers in southern Africa: exploring stories from Zimbabwean secondary school students", in Children's Geographies: Playing, Living, Learning Eds S L Holloway, G Valentine (Routledge, London) pp $174-193$

Sengendo J, Nambi J, 1997, “The psychological effect of orphanhood: a study of orphans in Rakai district" Health Transition Review 7 Supplement, 105-124

Silvey R, 2001, "Migration under crisis: household safety nets in Indonesia's economic collapse" Geoforum $3233-45$

Skeldon R, 1995, "The challenge facing migration research: a case for greater awareness" Progress in Human Geography $1991-96$

Smith F, Barker J, 2000, “'Out of school', in school: a social geography of out of school childcare”, in Children's Geographies: Playing, Living, Learning (Routledge, London) pp 245-256

Sporton D, Thomas D S G, Morrison J, 1999, "Outcomes of social and environmental change in the Kalahari of Botswana: the role of migration” Journal of Southern African Studies 25441 - 459

Townsend N W, 1997, "Men, migration and households in Botswana: an exploration of connections over time and space" Journal of Southern African Studies 23 405-420

UNAIDS, 1999 A Review of Household and Community Responses to the HIV/AIDS Epidemic in the Rural Areas of Southern Africa (UNAIDS, Geneva)

UNAIDS, 2000 Report on the Global HIV/AIDS Epidemic (UNAIDS, Geneva)

UNAIDS, 2004 Report on the Global HIV/AIDS Epidemic (UNAIDS, Geneva)

UNAIDS, UNICEF, USAID, 2002 Children on the Brink 2002: A Joint Report on Orphan Estimates and Program Strategies (USAID, Washington, DC)

UNAIDS, UNICEF, USAID, 2004 Children on the Brink 2004: A Joint Report on Orphan Estimates and Program Strategies (USAID, Washington, DC) 
Urassa M, Boerma J, Ng’weshemi J, Isingo R, Schapink D, Kumogola Y, 1997, “Orphanhood, child fostering and the AIDS epidemic in rural Tanzania" Health Transition Review 7 Supplement 2, $141-153$

Urassa M, Boerma J, Isingo R, Ngalula J, Ng'weshemi J, Mwaluko G, Zaba B, 2001, “The impact of HIV/AIDS on mortality and household mobility in rural Tanzania" AIDS 15 2017-2023

Valentine G, 1996, "Children should be seen and not heard: the production and transgression of adults' public space” Urban Geography $17205-220$

Williams B, Gouws E, Lurie M, Crush J, 2002, "Spaces of vulnerability: migration and HIV/AIDS in South Africa", Migration Policy Series number 24, South Africa Migration Project, Cape Town

Webb D, 1997 HIV and AIDS in Africa (Pluto Press, London)

WHO, UNICEF, 1994 Action for Children Affected by AIDS: Programme Profiles and Lessons Learned (WHO, Geneva and UNICEF, New York)

Wood W, 1988, “AIDS North and South: diffusion patterns of a global epidemic and a research agenda for geographers" The Professional Geographer 40 266-269

Young L, 2004, "Journeys to the street: the complex migration geographies of Ugandan street children" Geoforum 35471 - 488

Young L, Ansell N, 2003, "Fluid households, complex families: the impacts of children's migration as a response to HIV/AIDS in southern Africa" The Professional Geographer 55464 -476

Young L, Barrett H, 2001, "Adapting visual methods: action research with Kampala street children" Area $33141-152$ 
Conditions of use. This article may be downloaded from the E\&P website for personal research by members of subscribing organisations. This PDF may not be placed on any website (or other online distribution system) without permission of the publisher. 